\section{Brazilian normative data for the Short Form 36 questionnaire, version 2}

\section{Dados normativos brasileiros do questionário Short Form-36 versão 2}

\section{Josué Laguardia'}

Mônica Rodrigues Campos"

Claudia Travassos'

Alberto Lopes Najar"

Luiz Antonio dos Anjos"'I

Miguel Murat Vasconcellos (in memoriam)

'Institute of Communication and Scientific and Technological Information in Health, Fundação Oswaldo Cruz - Rio de Janeiro (RJ), Brazil.

"Department of Social Sciences, National School of Public Health, Fundação Oswaldo Cruz - Rio de Janeiro (RJ), Brazil.

"'Center of Medical Sciences, Departament of Social Nutrition, Universidade Federal Fluminense - Rio de Janeiro (RJ), Brazil.

\section{Abstract}

The 36-item Short Form (SF-36) survey is a widely used measure of health-related quality of life. Normative data are the key to determining whether a group or an individual scores above or below the average for their country, age or gender. Despite being used in many Brazilian studies, published norms with national comprehensiveness for the SF-36 have not been previously published. Methods: The study Pesquisa Dimensões Sociais das Desigualdades (PDSD) (Social Dimensions of Inequalities) involves 12,423 randomly selected Brazilian men and women aged 18 years old or more from urban and rural areas of the five Brazilian regions, and the information collected included the SF-36 as a measure of health-related quality of life. This provided a unique opportunity to develop age and gender-adjusted normative data for the Brazilian population. Results: Brazilian men scored substantially higher than women on all eight domains and the two summary component scales of the SF-36. Brazilians scored less than their international counterparts on almost all of SF-36 domains and both summary component scales, except on general health status (US), pain (UK) and vitality (Australia, US and Canada). Conclusion: The differences in the SF-36 scores between age groups, genders and countries confirm that these Brazilian norms are necessary for comparative purposes. The data will be useful for assessing the health status of the general population and of patient populations, and the effect of interventions on health-related quality of life.

Keywords: Quality of life. SF-36. Normative data. Survey. General population. Stratified random sample.

Corresponding author: Josué Laguardia, Instituto de Comunicação e Informação Científica e Tecnológica em Saúde, Avenida Brasil, 4.365, Pavilhão Haity Moussatché, Manguinhos, CEP: 21045-360, Rio de Janeiro, RJ, Brasil. E-mail: jlaguardia@cict.fiocruz.br

Financial support: National Council for Scientific and Technological Development - CNPq /

Project Institutos do Milênio - 001/2005 


\section{Resumo}

O questionário de 36 itens Short Form 36 (SF-36) é uma medida de qualidade de vida, relacionada à saúde, amplamente utilizada. Dados normativos são importantes para determinar se os escores de um grupo ou indivíduo estão acima ou abaixo da média do seu país, grupo etário ou sexo. A despeito do seu emprego em várias pesquisas no Brasil, dados normativos de abrangência nacional para o SF-36 não foram publicados previamente. Métodos: A Pesquisa Dimensões Sociais das Desigualdades (PDSD) é um inquérito que entrevistou 12.423 homens e mulheres brasileiros com idade de 18 anos e mais, selecionados aleatoriamente em áreas urbanas e rurais das cinco regiões brasileiras, e a informação coletada incluiu o SF-36 como uma medida de qualidade de vida relacionada à saúde. Isto proveu uma oportunidade única para desenvolver dados normativos ajustados por idade e sexo para a população brasileira. Resultados: Os escores dos homens brasileiros foram maiores que os das mulheres nos oito domínios e duas medidas componentes do SF-36. Os brasileiros tiveram pontuação mais baixa que seus respectivos contrapartes internacionais em quase todos os domínios e medidas componentes do SF-36, à exceção do estado geral de saúde (USA), dor (GB) e vitalidade (Austrália, USA e Canadá). Conclusão: As diferenças nos escores do SF-36 entre grupos etários, sexo e países confirmam que as normas brasileiras são necessárias para propósitos comparativos. Os dados serão úteis para avaliar o status de saúde da população em geral e dos pacientes, e o efeito das intervenções na qualidade de vida relacionada à saúde.

Palavras-chave: Qualidade de vida. SF-36. Dados normativos. Inquérito. População geral. Amostra aleatória estratificada.

\section{Introduction}

The standardized Short Form Health Survey 36 (SF-36) is an important tool for the assessment of quality of life ${ }^{1}$, and the comprehensiveness of its use in population surveys and in studies that analyze public policies and health status of patients ${ }^{2-6}$ can be verified by the references available in bibliographic data bases ${ }^{7}$ and the increasing number of validation studies in different countries and cultural contexts ${ }^{8}$. The purpose of this instrument is to detect clinical and socially relevant differences in the health status both of the general population and of people affected by a condition, as well as health-related changes throughout time ${ }^{9}$, by means of a reduced number of statistically efficient dimensions ${ }^{10}$.

The SF-36 is constituted of 36 questions, one that measures the transition from the health status in a period of one year and is not employed in the calculation of scales, and the others that are groups in eight scales or domains. Higher scores indicate better health status. The time to fulfill the questionnaire, from 5 to 10 minutes, and the versatility of its application by self-filling, telephone or personal interviews with people aged more than 14 years old, with reliability and validation levels that exceed the minimum recommended standards make this instrument an attractive tool to be combined with other population surveys.

In Brazil, the SF-36 was used in studies about quality of life of patients with terminal chronic renal insufficiency in outpatient hemodialysis ${ }^{11}$, arterial hypertension $^{12}$, submitted to hip fracture repair surgery ${ }^{13}$, living with HIV/AIDS ${ }^{14}$, and in a household survey of people living in the state of São Paulo ${ }^{15}$.

These studies shows that scores for the SF-36 domains obtained in adult populations presented high reliability and good criterion validity when compared to other instruments that assess the quality of life. The analysis of SF-36 data coming from a probabilistic sample of Brazilian households showed that the obtained scales meet the minimum 
psychometric standards required for quality of data, grading conjectures, reliability and validity of the instrument, and that these reproduce the physical and mental hypothetical dimensions. The relationship standards between factors and scales are predictive of their associations with external factors of physical and mental health ${ }^{16}$. Besides, this analysis enabled the estimation of national scores to determine if a group or individual is above or below the average for their country, age or gender.

Since health status is a social construction in which the assessment of the health of a person is made within a specific cultural comprehension of health ${ }^{17}$, and since the cross-cultural validity of an instrument should adopt the descriptive system developed internationally, but with scores calculated according to the variation observed in the specific population, it is essential to have Brazilian normative data in SF-36. Therefore, the objective of this article was to present the descriptive measures of the scale scores and measures composing the SF-36 according to age and age group obtained in a probabilistic sample of Brazilian households.

\section{Materials and Methods}

The sample is entirely probabilistic and stratified in multiple stages, which allows accurate inferences of population parameters.

The study Dimensões Sociais das Desigualdades (PDSD) (Social Dimensions of Inequalities) was a population-based household survey which interviewed, from July to December 2008, 12,423 heads of families and spouses living in 8,048 private households in common and non-special sectors (including slums) in all of the regions in Brazil, except for the rural zone of the North region.

Considering the analysis of inequalities, a sample stratum was created with the $10 \%$ richest census sectors in the research scope, with the objective of improving the precision of inequality indicators. The sample was in accordance with a probabilistic procedure in three stages, in which at first the cities were selected, followed by the census sectors inside the cities and, finally, the households inside the sectors. Basic information about schooling and work was collected for all of the individuals aged 10 years old or more. The percentage of holders in the households who answered to the research ranged from $96 \%$, in rural zones of the Northeast region, to $31 \%$, in the metropolitan area of Rio de Janeiro, and 23\% in the richest sectors of metropolitan areas.

In the health module of PDSD, among the several assessed aspects, the standard SF-36 v.2 was used after being translated to Portuguese. Questions concern the four weeks prior to the interview ${ }^{18}$. The eight SF-36 scales are: physical functioning (10 items), role-physical (4 items), bodily pain ( 2 items), general health (5 items), vitality (4 items), social functioning ( 2 items), role-emotional (3 items) and mental health (5 items), and there are two summary measures - physical health and mental health. The procedures to calculate scores were in accordance with the recommendations of the creators of SF-36 ${ }^{19}$. For each scale of SF-36, the following measures were taken: mean, respective confidence interval, ground and ceiling effect. The ground and ceiling effects are the percentage of subjects who had the lowest score - zero, or the highest score - one hundred - in each of the eight domains, respectively. In the case of physical and mental components, the expected minimum and maximum limits were used to calculate the ground and ceiling effects in the worst $($ score $=0)$ and best (score $=$ $100)$ health status. The adopted limiting values for the ground effect were scores lower than 20.2 physical health) and 17.4 (mental health); for the ceiling effect, scores higher than 57.9 (physical health) and 62.1 (mental health) ${ }^{1}$. Data of the heads of families and spouses were weighted to represent the total Brazilian population in the analyses conducted with SPSS v. $17^{16}$. The size of the sample obtained in this study meets the criteria established by the International Quality of Life Assessment (IQOLA) project for the comparison between genders and age groups ${ }^{17}$. 


\section{Results}

\section{Sample characteristics}

The response rate to SF-36 was of $100 \%$, and the quality indicator of the comprehension of the 15 pairs showed that only $7.4 \%$ were inconsistent for one pair of questions, while $7.3 \%$ showed inconsistency to 2 to 4 pairs of questions. The pair of answers that presented more inconsistency (3.7\%) combined the statement that taking a shower or getting dressed was too limiting, and the statement of not having limitations to perform vigorous activities. The distribution of items demonstrated that all of the categories were used by the respondents, with inclination towards the most favorable health status among male participants, aged less than 40 years old, with higher schooling.

The age-standardized scores for the eight scale domains and the two components (physical and mental health) of the SF-36 ranged according to age, being higher among the younger age groups and decreasing with age (Table 1). Even though several domains had shown ceiling effect $(60.6 \%$ in role-emotional and $58.5 \%$ in social functioning), this pattern was not observed in the ground effect (3.9\% for physical functioning and 3.8\% for role-physical).

As expected, mean scores of Brazilian men and women ranged according to age and gender (Tables 2 and 3). Among men, vitality in the younger age groups and general health in the other age groups presented with the lowest values. Among women, the scores of mental health in the age groups younger than 35 years old, as well as functional capacity, in age groups older than 64 years old, showed the lowest values. As in the general sample, several domains exhibited strong ceiling effect (86.9\% for men and $81.7 \%$ for women in social functioning), but only some domains presented this same pattern for the ground effect ( $4 \%$ for men and $3.9 \%$ for women in physical functioning). Men presented higher scores in relation to women for all of the domains and the two summary measures. Even though the confidence intervals are not superposed for any of the domains or summary measures, the magnitude of the difference should be considered. Except for general health and physical and mental health, all of the other domains had more than five points of difference, which is considered to be clinically and socially significant.

\section{Discussion}

The analysis of SF-36 data, applied in this Brazilian population sample, demonstrated good performance of the Brazilian version of this instrument, and that this questionnaire provides a valid measure of quality of life in the general population ${ }^{16}$. Therefore, the herein presented data can be a reference for studies of health inequalities in the country. Brazilian scores for the eight domains and the two summary measures of the SF-36 scale were similar to those of the United States, Australia, Canada and Great Britain ${ }^{5,20,21}$, but there is a pattern of lower scores in the sample for almost all of the domains in comparison to data from other countries, except for the scales of general health, higher than Great Britain; bodily pain, above the scores of Australia, the United States and Canada; and vitality, whose scores are higher than five when compared to Australian, north-American, Canadian and Great Britain scores.

The variability of scores by age, as observed in this study, points out to the need of using normative data according to age group when comparing the findings of studies that use the SF-36. The differences between countries can be a result of methodological matters, such as the sample population or the method used for data collection. The differences between genders in the Brazilian sample, whose men presented higher scores than women, are consistent with literature. Literature indicates that women tend to report worse health conditions. The voluntary participation of the interviewees in this investigation about the risk of biases is a characteristic of household surveys, which is a strategy shared by most of the population-based studies that used SF-36 in the world. An additional result of this 
Table 1 - Descriptive measures of the standardized scores for the eight domains of the 36-item Short Form and for the two summary measures (physical and mental health) of the Brazilian population by age groups.

Tabela 1 - Medidas descritivas dos escores padronizados das oito escalas e dos dois componentes do 36-item Short Form da população brasileira segundo faixa etária.

\begin{tabular}{|c|c|c|c|c|c|c|c|c|c|c|}
\hline Age group & $\mathrm{PH}$ & $\mathrm{RF}$ & $\mathrm{BP}$ & $\mathrm{GH}$ & VT & SF & $\mathrm{RE}$ & $\mathrm{MH}$ & Physical & Mental \\
\hline \multicolumn{11}{|c|}{ Up to 24 years old } \\
\hline \multicolumn{11}{|c|}{$(n=645)$} \\
\hline Mean & 91.4 & 87.8 & 85.8 & 79.8 & 77.4 & 89.9 & 88.1 & 76.5 & 55.2 & 51.8 \\
\hline $95 \% \mathrm{Cl}$ & $89.8-92.9$ & $86.0-89.5$ & $84.2-87.5$ & $78.3-81.3$ & $75.9-78.9$ & $88.4-91.4$ & $86.3-89.9$ & $75.0-78.0$ & $54.7-55.7$ & $51.0-52.5$ \\
\hline$\%$ ground & 2.0 & 0.5 & 0.2 & 0.0 & 0.0 & 0.6 & 1.4 & 0.2 & 0.2 & 0.8 \\
\hline$\%$ ceiling & 72.6 & 67.5 & 56.6 & 11.3 & 18.4 & 71.0 & 71.3 & 15.5 & 42.5 & 10.5 \\
\hline \multicolumn{11}{|c|}{$25-34$ years old } \\
\hline \multicolumn{11}{|c|}{$(n=2100)$} \\
\hline Mean & 89.7 & 88.4 & 86.1 & 80.1 & 76.9 & 90.6 & 89.4 & 76.9 & 54.9 & 52.3 \\
\hline $95 \% \mathrm{Cl}$ & $88.7-90.7$ & $87.4-89.3$ & $85.2-87.1$ & $79.3-80.9$ & $76.0-77.7$ & $89.8-91.4$ & $88.5-90.4$ & $76.0-77.8$ & $54.5-55.2$ & $51.9-52.7$ \\
\hline$\%$ ground & 2.1 & 1.2 & 0.7 & 0.1 & 0.2 & 0.4 & 1.3 & 0.1 & 0.1 & 0.8 \\
\hline \% ceiling & 70.5 & 70.3 & 58.6 & 11.0 & 14.6 & 71.9 & 73.7 & 16.3 & 43.5 & 10.6 \\
\hline \multicolumn{11}{|c|}{$35-44$ years old } \\
\hline Mean & 83.5 & 81.6 & 74.8 & 73.7 & 88.1 & 86.5 & 75.3 & 52.3 & 51.6 & 83.5 \\
\hline $95 \% \mathrm{Cl}$ & $82.5-84.6$ & $83.0-85.0$ & $80.7-82.5$ & $73.9-75.6$ & $72.9-74.5$ & $87.3-88.9$ & $85.6-87.4$ & $74.5-76.1$ & $52.0-52.7$ & $51.2-52.0$ \\
\hline$\%$ ground & 3.7 & 2.5 & 0.7 & 0.4 & 0.1 & 0.4 & 2.1 & 0.1 & 0.6 & 0.9 \\
\hline \% ceiling & 58.6 & 62.7 & 49.6 & 6.1 & 13.1 & 65.4 & 67.7 & 14.1 & 33.5 & 10.2 \\
\hline \multicolumn{11}{|c|}{$45-54$ years old } \\
\hline \multicolumn{11}{|c|}{$(n=2555)$} \\
\hline Mean & 76.5 & 78.8 & 75.5 & 69.3 & 71.7 & 84.0 & 82.2 & 74.1 & 49.4 & 50.9 \\
\hline $95 \% \mathrm{Cl}$ & $75.3-77.6$ & $77.7-79.9$ & $74.4-76.6$ & $68.4-70.2$ & $70.9-72.6$ & $83.1-84.9$ & $81.1-83.2$ & $73.2-74.9$ & $49.0-49.8$ & $50.5-51.4$ \\
\hline$\%$ ground & 3.3 & 3.0 & 1.6 & 0.4 & 0.3 & 0.7 & 3.2 & 0.2 & 0.8 & 0.9 \\
\hline \% ceiling & 43.2 & 53.7 & 41.8 & 4.4 & 13.6 & 58.1 & 61.1 & 14.5 & 23.7 & 13.4 \\
\hline \multicolumn{11}{|c|}{$55-64$ years old } \\
\hline Mean & 68.5 & 71.2 & 70.6 & 65.0 & 69.3 & 80.1 & 77.3 & 72.6 & 46.4 & 50.2 \\
\hline $95 \% \mathrm{Cl}$ & $67.2-69.8$ & $69.8-72.5$ & $69.3-71.8$ & $63.9-66.0$ & $68.3-70.3$ & $79.0-81.2$ & $76.0-78.6$ & $71.7-73.6$ & $45.9-46.8$ & $49.6-50.7$ \\
\hline$\%$ ground & 3.7 & 4.3 & 1.8 & 0.9 & 0.8 & 0.8 & 3.5 & 0.3 & 1.5 & 0.9 \\
\hline \% ceiling & 29.6 & 43.4 & 33.1 & 2.5 & 13.2 & 51.1 & 52.5 & 14.2 & 14.8 & 13.8 \\
\hline \multicolumn{11}{|c|}{$65-74$ years old } \\
\hline \multicolumn{11}{|c|}{$(n=1565)$} \\
\hline Mean & 58.2 & 65.1 & 68.4 & 60.7 & 67.2 & 76.6 & 73.1 & 73.2 & 43.2 & 50.2 \\
\hline $95 \% \mathrm{Cl}$ & $56.6-59.9$ & $63.4-66.7$ & $66.9-69.8$ & $59.5-61.9$ & $66.0-68.3$ & $75.3-77.9$ & $71.6-74.7$ & $72.1-74.3$ & $42.6-43.7$ & $49.6-50.8$ \\
\hline$\%$ ground & 5.6 & 7.2 & 2.3 & 1.4 & 0.8 & 1.2 & 4.9 & 0.1 & 1.7 & 0.8 \\
\hline \% ceiling & 16.4 & 34.5 & 31.0 & 1.8 & 10.8 & 44.2 & 45.8 & 14.4 & 8.6 & 15.4 \\
\hline \multicolumn{11}{|l|}{$\geq 75$ years old } \\
\hline Mean & 45.4 & 54.3 & 64.5 & 55.8 & 64.7 & 70.9 & 66.8 & 73.2 & 38.8 & 49.9 \\
\hline $95 \% \mathrm{Cl}$ & $43.0-47.8$ & $51.8-56.9$ & $62.3-66.6$ & $54.0-57.6$ & $62.9-66.4$ & $68.8-73.0$ & $64.4-69.3$ & $71.6-74.8$ & $38.0-39.7$ & $49.0-50.9$ \\
\hline$\%$ ground & 11.0 & 12.2 & 3.2 & 1.9 & 1.2 & 1.9 & 7.2 & 0.8 & 4.3 & 1.2 \\
\hline \% ceiling & 9.2 & 26.4 & 27.1 & 2.3 & 12.1 & 37.5 & 40.6 & 17.9 & 5.2 & 19.4 \\
\hline \multicolumn{11}{|l|}{$\begin{array}{l}\text { Total } \\
(n=12423)\end{array}$} \\
\hline Mean & 75.5 & 77.5 & 76.7 & 70.2 & 71.9 & 83.9 & 81.7 & 74.5 & 49.3 & 51.1 \\
\hline $95 \% \mathrm{Cl}$ & $74.9-76.0$ & $77.8-78.0$ & $76.3-77.2$ & $69.8-70.6$ & $71.5-72.3$ & $83.5-84.3$ & $81.2-82.2$ & $74.2-74.9$ & $49.1-49.5$ & $50.9-51.3$ \\
\hline$\%$ ground & 3.9 & 3.8 & 1.4 & 0.6 & 0.4 & 0.7 & 3.1 & 0.2 & 1.0 & 0.9 \\
\hline$\%$ ceiling & 44.9 & 53.3 & 43.3 & 5.5 & 13.4 & 58.5 & 60.6 & 14.9 & 25.5 & 12.8 \\
\hline
\end{tabular}

CF: Physical functioning; AF: role-physical; EGS: general health; VT: vitality; AS: social functioning; AE: role-emotional; SM: mental health. Source: Pesquisa Dimensões Sociais das Desigualdades, 2008.

CF: capacidade funcional; AF: aspectos físicos; EGS: estado geral de saúde; VT: vitalidade; AS: aspectos sociais; AE: aspectos emocionais; SM: saúde mental. Fonte: Pesquisa Dimensões Sociais das Desigualdades, 2008. 
Table 2 - Descriptive measures of the standardized scores for the eight domains of the 36-item Short Form and for the two summary measures (physical and mental component) of the Brazilian male population by age groups.

Tabela 2 - Medidas descritivas dos escores padronizados das oito escalas e dos dois componentes do 36-item Short Form da população masculina brasileira segundo faixa etária. Pesquisa Dimensões Sociais das Desigualdades, 2008.

\begin{tabular}{|c|c|c|c|c|c|c|c|c|c|c|}
\hline Age group & $\mathrm{PH}$ & $\mathrm{RF}$ & $\mathrm{BP}$ & $\mathrm{GH}$ & VT & SF & $\mathrm{RE}$ & $\mathrm{MH}$ & Physical & Mental \\
\hline \multicolumn{11}{|c|}{ Up to24 years old } \\
\hline \multicolumn{11}{|c|}{$(n=645)$} \\
\hline Mean & 95.3 & 89.8 & 90.6 & 83.7 & 80.4 & 93.1 & 90.0 & 80.9 & 56.6 & 53.4 \\
\hline $95 \% \mathrm{Cl}$ & $93.1-97.5$ & $87.0-92.6$ & $88.3-92.8$ & $81.5-85.9$ & $77.8-83.1$ & $91.1-95.1$ & $87.0-93.0$ & $78.6-83.2$ & $55.9-57.2$ & $52.2-54.6$ \\
\hline$\%$ ground & 1.9 & 0.0 & 0.0 & 0.0 & 0.0 & 0.0 & 1.9 & 0.0 & 0.0 & 0.0 \\
\hline \% ceiling & 85.4 & 70.1 & 66.0 & 14.6 & 25.8 & 78.0 & 76.9 & 22.5 & 49.0 & 14.4 \\
\hline \multicolumn{11}{|c|}{$\begin{array}{l}25-34 \text { years old } \\
(n=2100)\end{array}$} \\
\hline Mean & 92.0 & 90.6 & 89.8 & 83.2 & 81.3 & 92.8 & 90.0 & 82.1 & 55.7 & 54.4 \\
\hline $95 \% \mathrm{Cl}$ & $90.6-93.5$ & $89.2-92.0$ & $88.5-91.1$ & $82.1-84.3$ & $80.2-82.4$ & $91.7-93.8$ & $87.0-93.0$ & $81.0-83.2$ & $55.2-56.1$ & $53.8-54.9$ \\
\hline$\%$ ground & 2.2 & 1.2 & 0.8 & 0.0 & 0.1 & 0.4 & 1.2 & 0.0 & 0.0 & 0.1 \\
\hline$\%$ ceiling & 78.2 & 76.3 & 69.2 & 14.2 & 19.2 & 77.0 & 78.8 & 21.4 & 50.7 & 12.4 \\
\hline \multicolumn{11}{|c|}{$\begin{array}{l}35-44 \text { years old } \\
(n=2685)\end{array}$} \\
\hline Mean & 86.5 & 87.1 & 85.4 & 77.7 & 78.6 & 91.5 & 89.9 & 79.8 & 53.4 & 53.9 \\
\hline $95 \% \mathrm{Cl}$ & $84.9-88.1$ & $85.8-88.5$ & $84.1-86.7$ & $76.5-78.9$ & $77.6-79.7$ & $90.5-92.5$ & $88.7-91.1$ & $78.8-80.8$ & $52.8-53.9$ & $53.4-54.4$ \\
\hline$\%$ ground & 4.0 & 2.3 & 0.6 & 0.1 & 0.0 & 0.4 & 1.4 & 0.1 & 0.9 & 0.6 \\
\hline$\%$ ceiling & 67.2 & 67.8 & 58.4 & 8.0 & 17.4 & 72.2 & 73.8 & 18.1 & 37.7 & 11.9 \\
\hline \multicolumn{11}{|c|}{$45-54$ years old } \\
\hline Mean & 80.8 & 82.4 & 80.5 & 72.1 & 75.4 & 86.4 & 86.0 & 77.4 & 51.0 & 52.5 \\
\hline $95 \% \mathrm{Cl}$ & $79.1-82.6$ & $80.8-84.0$ & $79.0-82.1$ & $70.7-73.4$ & $74.2-76.6$ & $85.1-87.8$ & $84.5-87.5$ & $76.2-78.7$ & $50.4-51.6$ & $51.9-53.1$ \\
\hline$\%$ ground & 4.0 & 2.6 & 1.5 & 0.3 & 0.0 & 0.6 & 2.3 & 0.1 & 0.7 & 0.3 \\
\hline \% ceiling & 52.3 & 60.4 & 49.4 & 5.0 & 17.1 & 63.1 & 67.4 & 17.4 & 29.0 & 16.2 \\
\hline \multicolumn{11}{|c|}{$55-64$ years old } \\
\hline Mean & 74.3 & 75.9 & 76.8 & 67.2 & 74.0 & 84.3 & 81.2 & 77.1 & 48.3 & 52.2 \\
\hline $95 \% \mathrm{Cl}$ & $72.2-76.3$ & $73.8-78.0$ & $75.0-78.6$ & $65.5-68.8$ & $72.5-75.4$ & $82.7-85.8$ & $79.3-83.1$ & $75.7-78.5$ & $47.6-49.0$ & $51.4-52.9$ \\
\hline$\%$ ground & 3.8 & 4.5 & 1.4 & 1.0 & 0.5 & 0.8 & 2.9 & 0.5 & 1.2 & 0.6 \\
\hline \% ceiling & 39.0 & 52.6 & 41.3 & 3.9 & 17.2 & 59.3 & 60.2 & 19.1 & 19.1 & 15.9 \\
\hline \multicolumn{11}{|c|}{$65-74$ years old } \\
\hline Mean & 64.1 & 67.8 & 73.6 & 62.2 & 70.1 & 79.5 & 75.8 & 74.9 & 45.1 & 51.0 \\
\hline $95 \% \mathrm{Cl}$ & $61.7-66.6$ & $65.2-70.3$ & $71.4-75.8$ & $60.4-64.0$ & $68.4-71.9$ & $77.4-81.5$ & $73.5-78.2$ & $73.3-76.5$ & $44.2-45.9$ & $50.1-51.9$ \\
\hline$\%$ ground & 4.8 & 6.0 & 1.5 & 0.9 & 0.3 & 0.9 & 4.6 & 0.0 & 0.6 & 0.6 \\
\hline \% ceiling & 20.1 & 38.4 & 39.8 & 2.1 & 13.4 & 50.9 & 50.3 & 14.0 & 12.0 & 16.7 \\
\hline \multicolumn{11}{|l|}{$\begin{array}{l}\geq 75 \text { years old } \\
(n=754)\end{array}$} \\
\hline Mean & 48.0 & 56.0 & 67.6 & 56.5 & 68.0 & 73.8 & 68.3 & 76.8 & 39.5 & 51.5 \\
\hline $95 \% \mathrm{Cl}$ & $44.5-51.5$ & $52.2-59.8$ & $64.4-70.9$ & $53.9-59.1$ & $65.5-70.5$ & $70.8-76.8$ & $64.7-72.0$ & $74.7-79.0$ & $38.3-40.7$ & $50.3-52.8$ \\
\hline$\%$ ground & 9.3 & 10.2 & 2.7 & 1.5 & 0.3 & 0.6 & 6.3 & 0.0 & 5.1 & 0.6 \\
\hline \% ceiling & 9.0 & 28.8 & 31.0 & 1.5 & 12.1 & 39.9 & 41.7 & 20.2 & 5.7 & 19.3 \\
\hline \multicolumn{11}{|l|}{$\begin{array}{l}\text { Total } \\
(n=12423)\end{array}$} \\
\hline Mean & 79.4 & 80.7 & 81.4 & 72.7 & 76.0 & 86.9 & 84.8 & 78.5 & 50.7 & 52.9 \\
\hline $95 \% \mathrm{Cl}$ & $78.6-80.3$ & $79.9-81.4$ & $80.7-82.1$ & $72.1-73.4$ & $75.4-76.6$ & $86.3-87.5$ & $84.1-85.5$ & $78.0-79.0$ & $50.4-51.0$ & $52.6-53.1$ \\
\hline$\%$ ground & 4.0 & 3.4 & 1.2 & 0.5 & 0.2 & 0.6 & 2.5 & 0.1 & 0.9 & 0.4 \\
\hline$\%$ ceiling & 52.6 & 59.2 & 51.9 & 6.9 & 17.1 & 64.6 & 66.3 & 18.5 & 30.3 & 14.7 \\
\hline
\end{tabular}

CF: Physical functioning; AF: role-physical; EGS: general health; VT: vitality; AS: social functioning; AE: role-emotional; SM: mental health.

CF: capacidade funcional; AF: aspectos físicos; EGS: estado geral de saúde; VT: vitalidade; AS: aspectos sociais; AE: aspectos emocionais; SM: saúde mental. 
Table 3 - Descriptive measures of the standardized scores for the eight domains of the 36-item Short Form and for the two summary measures (physical and mental component) of the Brazilian female population by age groups.

Tabela 3 - Medidas descritivas dos escores padronizados das oito escalas e dos dois componentes do 36-item Short Form da população feminina brasileira segundo faixa etária. Pesquisa Dimensões Sociais das Desigualdades, 2008.

\begin{tabular}{|c|c|c|c|c|c|c|c|c|c|c|}
\hline $\mathrm{PH}$ & $\mathrm{RF}$ & $\mathrm{BP}$ & $\mathrm{GH}$ & VT & SF & $\mathrm{RE}$ & $\mathrm{MH}$ & Physical & Mental & $\mathrm{PH}$ \\
\hline \multicolumn{11}{|c|}{$\begin{array}{l}\text { Up to24 years old } \\
(n=645)\end{array}$} \\
\hline Mean & 89.4 & 86.8 & 83.5 & 77.9 & 75.8 & 88.3 & 87.2 & 74.3 & 54.5 & 50.9 \\
\hline $95 \% \mathrm{Cl}$ & $87.3-91.5$ & $84.5-89.0$ & $81.3-85.6$ & $75.9-79.9$ & $74.0-77.7$ & $86.3-90.3$ & $85.0-89.4$ & $72.5-76.2$ & $53.8-55.2$ & $49.9-51.9$ \\
\hline$\%$ ground & 2.1 & 0.7 & 0.2 & 0.0 & 0.0 & 0.9 & 1.2 & 0.2 & 0.20 & 1.2 \\
\hline$\%$ ceiling & 66.7 & 66.4 & 51.7 & 9.7 & 14.7 & 67.7 & 68.4 & 12.0 & 39.2 & 8.6 \\
\hline \multicolumn{11}{|c|}{$\begin{array}{l}25-34 \text { years old } \\
(n=2100)\end{array}$} \\
\hline Mean & 87.8 & 86.6 & 83.3 & 77.7 & 73.4 & 88.9 & 87.9 & 72.9 & 54.2 & 50.7 \\
\hline $95 \% \mathrm{Cl}$ & $86.5-89.2$ & $85.2-87.9$ & $82.0-84.6$ & $76.5-78.9$ & $72.2-74.5$ & $87.7-90.0$ & $86.6-89.2$ & $71.7-74.1$ & $53.8-54.6$ & $50.1-51.2$ \\
\hline$\%$ ground & 2.0 & 1.2 & 0.7 & 0.3 & 0.3 & 0.5 & 1.4 & 0.3 & 0.2 & 1.4 \\
\hline$\%$ ceiling & 64.6 & 65.9 & 50.5 & 8.6 & 11.0 & 67.8 & 70.1 & 12.2 & 37.9 & 9.2 \\
\hline \multicolumn{11}{|c|}{$\begin{array}{l}35-44 \text { years old } \\
(n=2685)\end{array}$} \\
\hline Mean & 81.2 & 81.5 & 78.6 & 72.4 & 69.7 & 85.4 & 83.8 & 71.7 & 51.5 & 49.8 \\
\hline $95 \% \mathrm{Cl}$ & $79.8-82.6$ & $80.1-82.9$ & $77.3-79.9$ & $71.3-73.6$ & $68.6-70.8$ & $84.3-86.5$ & $82.5-85.1$ & $70.6-72.8$ & $51.1-52.0$ & $49.2-50.3$ \\
\hline$\%$ ground & 3.3 & 2.6 & 0.9 & 0.5 & 0.3 & 0.3 & 2.7 & 0.1 & 0.5 & 1.1 \\
\hline$\%$ ceiling & 51.5 & 58.7 & 42.5 & 4.7 & 9.8 & 60.0 & 63.0 & 11.0 & 30.2 & 8.9 \\
\hline \multicolumn{11}{|c|}{$\begin{array}{l}45-54 \text { years old } \\
(n=2555)\end{array}$} \\
\hline Mean & 73.3 & 76.2 & 71.9 & 67.2 & 69.1 & 82.2 & 79.4 & 71.6 & 48.3 & 49.7 \\
\hline $95 \% \mathrm{Cl}$ & $71.7-74.8$ & $74.6-77.7$ & $70.4-73.3$ & $66.0-68.4$ & $67.9-70.2$ & $81.0-83.5$ & $77.9-80.8$ & $70.4-72.7$ & $47.7-48.8$ & $49.1-50.3$ \\
\hline$\%$ ground & 2.8 & 3.3 & 1.6 & 0.5 & 0.5 & 0.6 & 3.8 & 0.3 & 0.8 & 1.4 \\
\hline$\%$ ceiling & 36.6 & 48.9 & 36.0 & 4.0 & 11.1 & 54.5 & 56.4 & 12.3 & 19.8 & 11.4 \\
\hline \multicolumn{11}{|c|}{$\begin{array}{l}55-64 \text { years old } \\
(n=2120)\end{array}$} \\
\hline Mean & 64.5 & 67.9 & 66.2 & 63.4 & 66.0 & 77.2 & 74.6 & 69.5 & 45.0 & 48.8 \\
\hline $95 \% \mathrm{Cl}$ & $62.8-66.2$ & $66.2-69.7$ & $64.5-67.9$ & $62.1-64.8$ & $64.7-67.3$ & $75.7-78.6$ & $72.9-76.3$ & $68.2-70.8$ & $44.4-45.6$ & $48.1-49.5$ \\
\hline$\%$ ground & 3.7 & 4.3 & 2.2 & 1.0 & 1.0 & 0.8 & 4.0 & 0.2 & 1.7 & 1.2 \\
\hline$\%$ ceiling & 23.1 & 37.0 & 27.4 & 1.7 & 10.4 & 45.3 & 47.2 & 10.7 & 11.8 & 12.3 \\
\hline \multicolumn{11}{|c|}{$\begin{array}{l}65-74 \text { years old } \\
(n=1565)\end{array}$} \\
\hline Mean & 54.0 & 63.2 & 64.7 & 59.7 & 65.1 & 74.6 & 71.2 & 72.0 & 41.8 & 49.7 \\
\hline $95 \% \mathrm{Cl}$ & $51.9-56.2$ & $61.0-65.3$ & $62.7-66.6$ & $58.0-61.3$ & $63.5-66.6$ & $72.8-76.3$ & $69.1-73.2$ & $70.5-73.5$ & $41.1-42.6$ & $48.9-50.5$ \\
\hline$\%$ ground & 6.1 & 8.1 & 2.8 & 1.8 & 1.2 & 1.3 & 5.0 & 0.1 & 2.4 & 0.9 \\
\hline \% ceiling & 13.9 & 31.7 & 24.9 & 1.5 & 9.1 & 39.6 & 42.5 & 14.7 & 6.3 & 14.4 \\
\hline \multicolumn{11}{|c|}{$\begin{array}{l}\geq 75 \text { years old } \\
(n=754)\end{array}$} \\
\hline Mean & 43.3 & 53.0 & 61.9 & 55.3 & 62.1 & 68.6 & 65.6 & 70.3 & 38.3 & 48.7 \\
\hline $95 \% \mathrm{Cl}$ & $40.0-46.6$ & $49.6-56.4$ & $59.0-64.9$ & $52.7-57.8$ & $59.7-64.5$ & $65.7-71.6$ & $62.3-68.9$ & $68.0-72.6$ & $37.2-39.5$ & $47.4-50.0$ \\
\hline$\%$ ground & 12.4 & 14.0 & 3.6 & 2.1 & 1.7 & 2.9 & 7.8 & 1.4 & 3.6 & 1.9 \\
\hline \% ceiling & 9.3 & 24.5 & 24.3 & 2.9 & 11.8 & 35.9 & 39.9 & 16.2 & 4.8 & 19.7 \\
\hline \multicolumn{11}{|l|}{$\begin{array}{l}\text { Total } \\
(n=12423)\end{array}$} \\
\hline Mean & 72.5 & 75.2 & 73.4 & 68.3 & 68.9 & 81.7 & 79.5 & 71.6 & 48.3 & 49.7 \\
\hline $95 \% \mathrm{Cl}$ & $71.8-73.3$ & $74.5-75.9$ & $72.7-74.0$ & $67.8-68.9$ & $68.3-69.4$ & $81.1-82.3$ & $78.8-80.1$ & $71.1-72.1$ & $48.1-48.6$ & $49.5-50$ \\
\hline$\%$ ground & 3.9 & 4.1 & 1.6 & 0.8 & 0.6 & 0.8 & 3.5 & 0.3 & 1.1 & 1.2 \\
\hline$\%$ ceiling & 39.3 & 49.1 & 37.1 & 4.5 & 10.7 & 54.1 & 56.4 & 12.2 & 22.1 & 11.4 \\
\hline
\end{tabular}

CF: Physical functioning; AF: role-physical; EGS: general health; VT: vitality; AS: social functioning; AE: role-emotional; SM: mental health; CoF: physical component summary; CoM: mental component summary.

CF: capacidade funcional; AF: aspectos físicos; EGS: estado geral de saúde; VT: vitalidade; AS: aspectos sociais; AE: aspectos emocionais; SM: saúde mental; CoF: componente físico; CoM: componente mental. 
study was the analysis of factors that can be used as weight to calculate the summary measures of physical and mental health in the second Brazilian version of SF-36, to be applied in urban and rural Brazilian populations.

The data in this study were obtained by a complex sample that represents Brazilian households. The information collected in this study concern 12,423 individuals living in 8,048 private households in common and non-special sectors (including slums) of all of the regions in Brazil, in urban and rural areas. Therefore, the results represented the set of the Brazilian population, and not necessarily the demographic strata used in this analysis.

\section{Conclusion}

SF-36 was built to provide a useful score profile in order to understand the population differences with regard to physical and mental health status, to chronic diseases and other medical conditions, and also to assess the effect of treatments on the general health status.

However, in order for the normative data of SF-36 to be valid, they should be originated from a representative sample of the population of interest. The perspective is that these values can be used for comparison with findings from other studies that use the SF-36 v.2 or the calculation of scores in further investigations involving the Brazilian population and its segments.

\section{References}

1. Taft C, Karlsson J, Sullivan M. Do SF-36 summary components scores accurately summarize subscale scores? Qual Life Res 2001; 10: 395-4046.

2. McHorney CA, Ware JE, Lu JFR, Sherbourne CD. The MOS 36-item Short Form Health Survey (SF-36): III. Tests of data quality scaling assumptions and reliability across diverse patient groups. Med Care 1994; 32: 40-66.

3. Jenkinson C, Layte R, Coulter A, Wright L. Evidence for the sensitivity of the SF-36 health status measure to inequalities in health: results from the Oxford healthy lifestyles survey. J Epidemiol Community Health 1996; 50: 377-80.

4. McDowell I., Newell C. Measuring health: a guide to rating scales and questionnaires. 2nd edition. New York: Oxford University Press; 1996.

5. Ware JE. SF-36 Health Survey Update. Spine 2000; 25(24): 3130-9.

6. Wilson D, Parsons J, Tuckerr G. The SF-36 summary scales: problems and solutions. Soz-Praventivmed 2000; 45: 239-46.

7. Hawthorne G, Osborne RH, Taylor A, Sansoni J. The SF36 version 2: critical analyses of population weights, scoring algorithms and population norms. Qual Life Res 2007; 16: 661-73.

8. Gandek B, Ware JE, Aaronson NK, Alonso J, Apolone G, Bjorner J, et al. Tests of data quality scaling assumptions and reliability of the SF-36 in eleven countries: results from the IQOLA Project. J Clin Epidemiol 1998; 51: 1149-58.

9. Ware JE, Sherbourne CD. The MOS 36-Item Short Form Health Survey (SF-36) I. Conceptual framework and item selection. Med Care 1992; 30: 473-83.

10. Jenkinson C, Layte R., Lawrence K. Development and testing of the Medical Outcomes Study 36-Item Short Form Health Survey Summary Scale scores in the United Kingdom. Results from a large-scale survey and a clinical trial. Medl Care 1997; 35: 410-6.
11. Souza FF. Avaliação da qualidade de vida do idoso em hemodiálise: comparação de dois instrumentos genéricos [Dissertação]. Campinas: Faculdade de Ciências Médicas da Universidade Estadual de Campinas; 2004. 167 p.

12. Silqueira SMF. O questionário genérico SF-36 como instrumento de mensuração da qualidade de vida relacionado à saúde de pacientes hipertensos [Tese]. Ribeirão Preto: Escola de Enfermagem da Universidade de São Paulo; 2005. 112 p.

13. Mendonça TMS. Avaliação prospectiva da qualidade de vida relacionada à saúde em idosos com fratura do quadril por meio de um instrumento genérico - The Medical Outcome Study - 36-item Short-Form Health Survey (SF-36) [Dissertação]. Uberlândia: Faculdade de Medicina, Universidade Federal de Uberlândia; 2006. 119 p.

14. Soárez PC, Castelo A, Abrão P, Holmes WC, Ciconelli RM. Tradução e validação de um questionário de avaliação de qualidade de vida em AIDS no Brasil. Rev Panam Salud Publica 2009; 25: 69-76.

15. Lima MG, Barros MBA, César CLG, Goldbaum M, Carandina L, Ciconelli RM. Health related quality of life among the elderly: a population-based study using SF-36 survey. Cad Saúde Pública 2009; 25: 2159-67.

16. Laguardia J, Campos MR, Travassos CM, Najar AL, Anjos LA, Vasconcellos MM. Psychometric evaluation of the SF-36 (v.2) questionnaire in a probability sample of Brazilian households: results of the survey Pesquisa Dimensões Sociais das Desigualdades (PDSD), Brazil 2008. Health and Quality of Life Outcomes 2011; 9: 61.

17. Gandek B, Ware JE. Methods for validating and norming translations of health Status Questionnaires: The IQOLA Project Approach. J Clin Epidemiol 1998; 51: 953-9.

18. Campolina AG, Ciconelli RM. O SF-36 e o desenvolvimento de novas medidas de avaliação da qualidade de vida. Acta Reumatol Port 2008; 33: 127-33. 
19. Ware JE, Kosinki M, Gandek B. SF-36 Health Survey: Manual \& Interpretation Guide. Lincoln RI: QualityMetric; 2000.

20. Bowling A, Bond M, Jenkinson C, Lamping DE. Short Form 36 (SF-36) Health Survey questionnaire: which normative data should be used? Comparisons between the norms provided by the Omnibus Survey in Britain, the Health Survey for England and the Oxford Healthy Life Survey. Journal of Public Health Medicine 1999; 21(3): 255-70.
21. Hopman WM, Towheed T, Anastassiades T, Tenenhouse A, Poliquin S, Berger C, et al. The Canadian Multicentre Osteoporosis Study Research Group. Canadian normative data for the SF-36 health survey. CMAJ 2000; 163(3): 265-71.

Received on: $10 / 31 / 12$

Final version presented on: 08/05/13

Accepted on: 08/07/13 